\title{
LOXIA ENUCLEATOR.
}

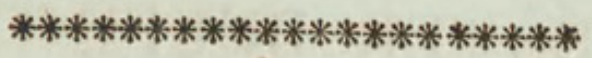

CHARACTER GENERICUS.

Rostrum conico-gibbum, frontis basi rotundatum versus caput; mandibula inferiore margine laterali inflexa.

Nares in basi rostri.

Lingua integra.

Lin. Syst. Nat. p. 299.

CHARACTER SPECIFICUS, E。.

LOXIA rosea, alis candaque nigris, tectricibus albo marginatis.

LOXIA linea alarum duplici alba, rectricibus totis nigricantibus.

Lin. Syst. Nat. p. 299.

Coccothraustes Canadensis.

$$
\text { Briss. 3. p. } 250 .
$$

Apud Britannos non nisi in partibus septentrionalibus, idque rarius, conspicitur formosa hæc acis, Loxia Pyrrhula fere duplo Major. Semina præcipue depascitur e conis pinorum et abietum rostro extracta. Feminæ color est olivaceus. 


\section{GREATER BULFINCH.}

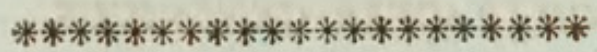

GENERIC CHARACTER.

Bill thick and convex.

Nostrils small.

Tongue truncated.

SPECIFIC CHARACTER, छं.

Rose-red Grosbeak, with black wings and tail ; the coverts edged with white.

Greatest BULFINCH.

$$
\text { Edw. pl. } 123 .
$$

Pine Grosbeak.

$$
\text { Penn. Brit. Zool. }
$$

Gros-Bec du Canada.

$$
\text { Pl. Enl. 135. f. } 1 .
$$

This beautiful bird, which is a rare species in England, being only observed occasionally in the northern counties, is nearly twice the size of the common Bulfinch. It feeds principally on the seeds of firs and pines, which it picks out of the cones. The female is of an olive colour. 


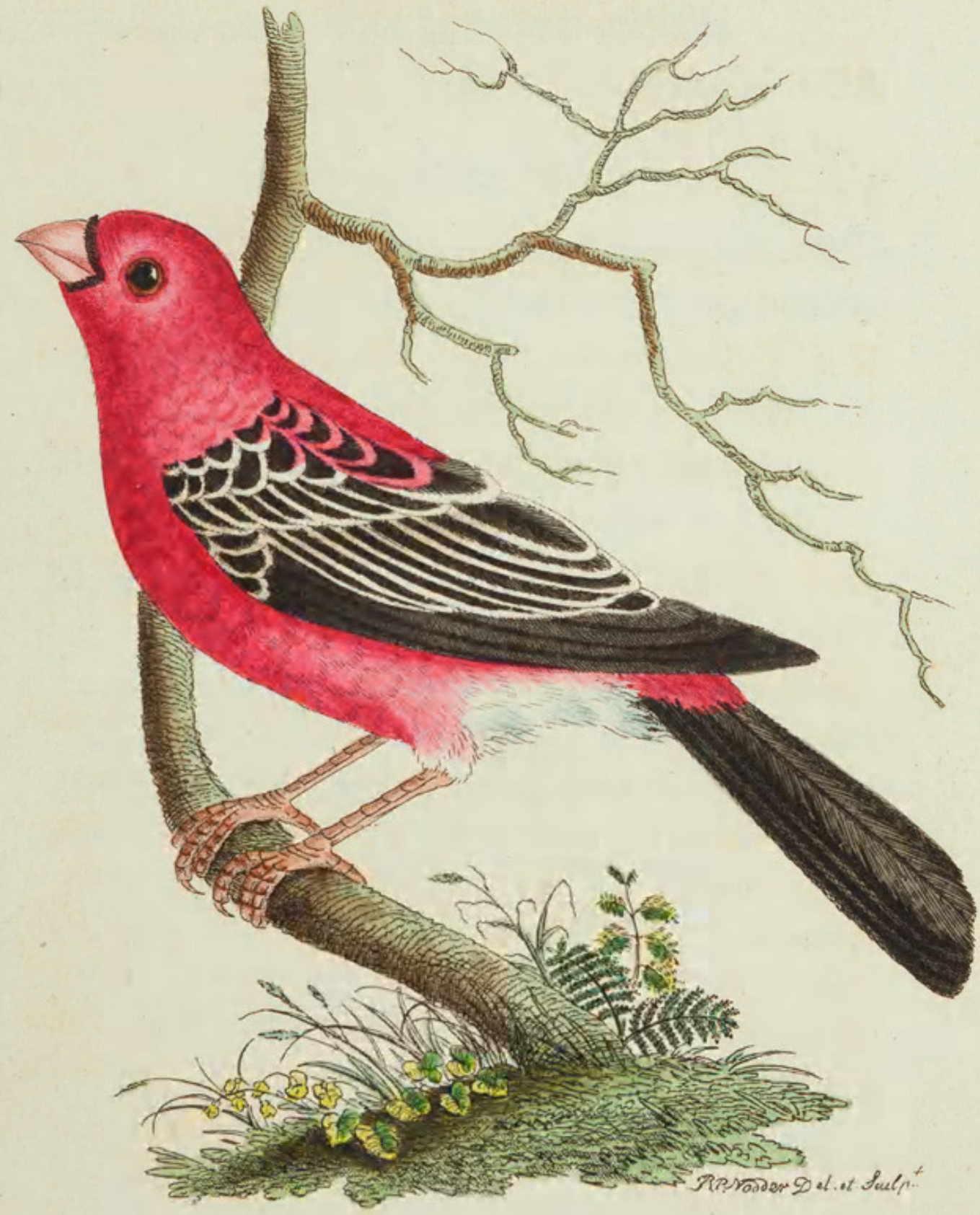




\section{$2 \mathrm{BHL}$ Biodiversity Heritage Library}

Shaw, George. 1806. "The Greater Bulfinch, Loxia enucleator [PI. 685]." The Naturalist's Miscellany 17(CXCVIII), https://doi.org/10.5962/p.311123.

View This Item Online: https://www.biodiversitylibrary.org/item/281954

DOI: https://doi.org/10.5962/p.311123

Permalink: https://www.biodiversitylibrary.org/partpdf/311123

\section{Holding Institution}

Museums Victoria

\section{Sponsored by}

Atlas of Living Australia

\section{Copyright \& Reuse}

Copyright Status: Public domain. The BHL considers that this work is no longer under copyright protection.

This document was created from content at the Biodiversity Heritage Library, the world's largest open access digital library for biodiversity literature and archives. Visit BHL at https://www.biodiversitylibrary.org. 